\title{
292sTE BESTUURSVERGADERING
}

GEHOUDRN 21 APRIL 1888.

Tegenwoordig de hh. Kern (Voorzitter), Kielstra (Ondervoorzitter), J. H. de Groot (Penningmeester), Bool, Martin, de Roo, Snouck Hurgronje, Wilken, Niemann, Riedel, Humme en Wijnmalen (Secretaris).

De notulen van het verhandelde in de vorige vergadering worden gelezen en goedgekeurd.

De heer Snouck Hurgronje deelt mede, dat hij van sommige leden weder klachten heeft vernomen over de verzending der Werken en Bijdragen van het Instistuut, welke zij of niet, of eerst last ontvangen. Hij verzoekt dat hiervan asnteekening in de notulen geschiede.

Naar aanleiding dezer mededeeling wordt, overeenkomstig het voorstel des Voorzitters, hesloten den Seeretaris te machtigen hieromtrent met den drukker van hef Instituat, die tevens met de verzending der werken is belast, in onderhandeling te treden en de noodige matregelen te nemen ter verzekering eener geregelde en spoedige verzending, zullende, zoo dit ondoenlijk moeht bljiken, wijziging van het bestamde contract in overweging worlen genomen.

Door den Secretaris wordt mededeeling gedaan wan de sedert de vorige vergadering outvangen boekwerken, die, onder dankzegging an de inzenders, in de boekerij worlen geplaatst. Tevens wordt berieht, dat is ingeleomen een sehrijven van let Indis Office van 29 Mart II., hondende lenniggening dat vanwege het Indiseh Gouvernement, ter ambieding an het Instituat, is ontvangen het 29e deel nan de $"$ Reports of the areliaeological Survey of Indian, met een $n$ fienteral Index op de geheele serie, met verzoel te mogen vernemen of de vorige declen, hetzij allen, hetzij gedeeltelijk in de boekery van het Institunt aanwerig zyjn.

De Secretaris deelt mede, daf slechts de zes eerste deelen, gefurende de jaren $1871 / 78$ uitgegeren, ontrangen aju, to geen aan den Undersecrettary of Stute for India ad woden medegedeeld, ouder aanvaarding van zijn anbed tot aanvulling der reeks. 
Verder zijn ingekomen:

10. eene missive van de Koninklijke Akademie van Wetenschappen te Amsterdam, houdende dankzegging voor de gezonden Bijdragen, 5e reeks, deel III, afl. 1. en voor het 2 e gedeelte van Bock's reis in Oost- en Zuid-Borneo.

Voor kennisgeving aangenomen.

20. eene missive van den Secretaris des Nass. Vereins für Naturkunde, waarbij wordt verzocht de voor zijn genootschap bestemde edita van het Instituut naar Wiesbaden te willen zenden.

Hiervan wordt aanteekening gehouden.

30. eene missive van den Bibliothecaris van de Reale Accademia dei Iincei, te Rome, houdende verzoek om, zoo mogelijk, ter aanvulling der reeks van de Instituutswerken, te mogen ontvangen de eerste aflevering van deel VI, $4^{\theta}$ volgreeks, der Bijdragen.

De Secretaris wordt gemachtigd, zoo mogelijk, aan dit verzoek te voldoen.

40. Eene missive van den heer van J. P. Th, van Nunen, te Amsterdam, houdende bericht van de aanvaarding van het lidmatschap van het Institunt.

50. cene missive van den heer J. W. Maxwell, te Penang, waarbij hij, onder dankbetuiging voor de hem verleende onderscheiding, verklaart gasme zijne benoeming tot buitenlandsch lid van het Instituut te aanvaarden.

De missives sub $40 \mathrm{ens}$ jo worden voor kemnisgeving asugenomen, terwijl nog worlt angeteekend, dat wegens overlijden van de lijst der buitenlandsche leden moeten worden afgevoerd Prof. H. L. Fleischer, te Leipzig, Sir Walter Blliot Wolfelee (Schotland) en Pandit Bhagwânilal Indraji, te Bombay.

Van het buitenlandsch lid, den Graaf Meyners d'Lstrey te Parijs, is ingekomen cen sehrijven, warbij, onder mededeeling van het bestande plan tot het houden van een Geographisch Congres te Parijs ter gelegenheid der tentoonstelling in 1889, het verzoek wordt gedaan, om, evenals in 1878 , ook nu weder het Instituut daarbij te mogen vertegeuwoordigen.

Overeenkomstig het voorstel des Voorzitters worlt besloten ontrent dit verzoek vooralsuog geene beslissing te nemen. 
Ten vervolge van hun schrijuen van 25 Januari jl. no. B/154, bieden Commisarissen te Batavia, onder geleide eener missive dd. 10 Februari jl. $\mathrm{n} 0, \mathrm{~B} / 155$, eene prima-wissel aan, groot $f 305.25$ N. C., betaalbaar zes maanden na dato, welk bedrag het kassaldo op 1 Januari van dit jaar vertegenwoordigt, vermeerderd met hetgeen sedert ontvangen werd.

De wissel is bereids aan den Penningmeester ter hand gesteld, terwijl de ontvangst daarvan zal worden erkend.

De Secretaris doet mededeeling van den inhoud der met 1 Juli a. s. uit te geven derde aflevering van de Bijdragen, waaruit blijkt dat, met het oog op het wenschelijke eener plaatsing van de uitgebreide artikelen der heeren Kielstra, van Langen en Wilken, de affevering zeer omvangrijk zal zijn, waarom hij machtiging vraagt en erlangt het voor elk nummer vastgesteld aantal vellen ditmaal te mogen overschrijden, met dien verstande echter, dat de October-affevering eenigszins zal worden ingekrompen.

De Secretaris geeft uitvoerig verslag van de door hem met de firma Brill en den heer Snouck Hurgronje gevoerde nadere onderhandelingen betreffende de voorgenomen uitgave van het werk van laatstgenoemde, in verband met de vroeger daaromtrent gemaakte voorloopige berekening van kosten als anderzins.

Overeenkomstig zijn voorstel, nader toegelicht en ondersteund door den Heer Snouck Hurgronje, wordt besloten :

10. dat de uitgave zal geschieden in 2 dln. in gr. 8 vo format, te zamen \pm 35 à 40 vellen druks, terwijl de platen zullen worden vereenigd in éen afzonderlijken Atlas in gr. 40.;

20. dat van den tekst en de platen, voor zoover deze litho- en chromolithographiën betreft, eene oplaag zal worden geleverd van 800 exemplaren, terwijl voorloopig van de te leveren photographische platen 500 exemplaren zullen worden bezorgd;

30. dat zal worden gebruik gemaakt van het voorstel des heeren Trap te Leiden, om van een drietal platen van het werk des heeren Snouck Hurgronje in het Internationale Archief voor ethnographie te mogen opnemen, waarvoor de firma zich verbindt kosteloos zoovele afdrukken af te staan als voor de oplaag van bedoeld werk noodig zal zijn;

40, dat, in de plaats van honorarium, 40 exemplaren van het werk aan dẹ Schrij̣ver zullen worden toegekend; 
50. dat de prijs, waarvoor het werk zal worden in den handel gebracht, tot $f 20$ à $f 25$ dient verhoogd, doch eerst later definitief zal worden bepaald, met handhaving echter van de som van $f 15$ voor elk der 100 exemplaren, die aan het Ministerie van Koloniën zullen moeten worden bezorgd;

60. dat, eindelijk, met het oog op den nu eerst bekenden omvang der geheele uitgave, de kosten daarvan geraamd worden tot een bedrag van $f 4,500$ à $f 5,000$.

Overeenkomstig den door den heer Wilken gegeven wenk verklaart de Secretaris zich bereid, in overleg met den Schrijver en den Uitgever een prospectus van het werk te doen samenstellen ter verspreiding onder de leden, voor wie het, ingevolge vroeger genomen besluit, tegen de helft van den handelsprijs zal worden verkrijgbaar gesteld.

De heer Snouck Hurgronje bespreekt de nitgave der Atjehsche grammatica en chrestomathie, benevens die van het woordenboek. Kan met den druk van het woordenboek eerst in den loop van dit jaar een aanvang worden gemaakt, met het oog echter op het aanstaand vertrek des heeren van Langen en het alleszins wenschelijke dat hij zelf de drukproeven nazie, wordt in overweging gegeven onverwijld over te gaan tot het drukken van de spraakkunst met chrestomathie, welke ongeveer op 6 vellen druks kan worden geraamd.

$\mathrm{Na}$ eenige gedachtenwisseling wordt dienovereenkomstig besloten en de Secretaris gemachtigd daartoe de noodige maatregelen te nemen en het daarheen te leiden, dat de druk, althans van de spraakkunst, voor het vertrek van den Schrijver in Juni, zal zijn afgeloopen.

Niets meer hierna aan de orde zijnde, wordt de vergadering door den Voorzitter gesloten. 